\title{
Value of Forced Diuresis in Acute Barbiturate Poisoning
}

\author{
G. E. MAWER,* PH.D., M.R.C.P.ED. ; H. A. LEE, $\dagger$ B.SC., M.R.C.P.
}

Erit. med. F., 1968, 2, 790-793

The therapeutic usefulness of forced diuresis in severe barbiturate poisoning has yet to be evaluated by a controlled clinical trial. In the absence of such a trial its usefulness can be judged only indirectly from urinary barbiturate excretion rates. Unfortunately, however, the rate of apparent barbiturate excretion varies with the method of its measurement.

The usual clinical laboratory procedures (Varley, 1967) depend on chloroform or ether extraction of barbiturate followed by spectrophotometric estimation. When applied to biological fluids they estimate not only unchanged barbiturate hypnotic but also a proportion of the metabolic derivatives (Bloomer, 1967). The resultant error is small when plasma is extracted, for the concentrations of unchanged barbiturate hypnotic and metabolites are of the same order in plasma. When urine is extracted, however, the error may be large, for the concentrations of metabolites may be several times greater than the concentration of unchanged barbiturate.

Using more selective methods, Bloomer (1965, 1966) found that the urinary excretion of unchanged pentobarbitone and quinalbarbitone during forced diuresis was only a minor factor in the elimination of these drugs.

Linton, Luke, and Briggs (1967) described the results of forced diuresis in 110 patients with severe barbiturate poisoning. They concluded that the barbiturate excretion rates justified forced diuresis in cases of poisoning by long-acting barbiturates and by cyclobarbitone. They also concluded that forced diuresis was useful in cases of poisoning by intermediate-acting barbiturates if the blood level had reached $4 \mathrm{mg} . / 100 \mathrm{ml}$. and that mannitol had no practical advantages over frusemide. However, these conclusions were based on a method of barbiturate estimation which is not specific for unchanged hypnotic.

The present report describes the pattern of barbiturate excretion in four pairs of patients poisoned by pentobarbitone, amylobarbitone, butobarbitone, and phenobarbitone. Forced diuresis was induced with mannitol and frusemide, and the following were determined: (1) the rate of excretion of specifically identified unchanged barbiturate hypnotic ; (2) the extent to which the excretion rate was exaggerated by a less specific assay technique; (3) the rate of excretion of derivatives of barbituric acid, both unchanged barbiturate hypnotic and metabolites; and (4) the relative effects of frusemide and mannitol on the urinary excretion of unchanged barbiturate hypnotic.

\section{Methods}

The eight patients were admitted to the respiratory care unit of the Manchester Royal Infirmary during 1967. Brief clinical details are given in Table I. In no case could the dose of hypnotic administered be determined with confidence. Gastric aspiration and lavage were carried out when the patient was received within four hours of administration. Six patients required an endotracheal tube and mechanical ventilation. Two rejected an endotracheal tube and maintained satisfactory arterial blood gas tensions while breathing air spontaneously. One patient (Case 2) had consumed 5 pints (2.8 litres) of beer

\footnotetext{
* Senior Lecturer in the Department of Pharmacology and Therapeutics, University of Manchester.

t Lecturer in Medicine, University of Manchester. Now Consultant Physician at St. Mary's Hospital, Portsmouth.
}

before the overdose of hypnotic. Two patients (Cases 7 and 8) were epileptics who had received phenobarbitone and one other anticonvulsant for many years.

TABLE I.-Clinical Features of Eight Patients with Acute Barbiturate Poisoning

\begin{tabular}{|c|c|c|c|c|c|}
\hline $\begin{array}{l}\text { Case } \\
\text { No. }\end{array}$ & $\begin{array}{l}\text { Age } \\
\text { and } \\
\text { Sex }\end{array}$ & Barbiturate & Airway & Ventilation & $\begin{array}{c}\text { Total } \\
\text { Hours } \\
\text { Uncon- } \\
\text { scious }\end{array}$ \\
\hline $\begin{array}{l}1 \\
2 \\
3 \\
4\end{array}$ & $\begin{array}{ll}31 & F \\
45 & F \\
69 & F \\
50 & F\end{array}$ & $\begin{array}{l}\text { Pentobarbitone } \\
\text { Pentobarbitone } \\
\text { Amylobarbitone } \\
\text { Amylobarbitone, } \\
\text { quinalbarbitone }\end{array}$ & $\begin{array}{l}\text { Endotracheal } \\
\text { Endotracheal } \\
\text { Phatyngeal } \\
\text { Endotracheal }\end{array}$ & $\begin{array}{l}\text { Assisted } \\
\text { Assisted } \\
\text { Spontaneous } \\
\text { Assisted }\end{array}$ & $\begin{array}{l}40 \\
24 \\
30 \\
48\end{array}$ \\
\hline $\begin{array}{l}5 \\
6 \\
7 \\
8\end{array}$ & $\begin{array}{ll}20 & \mathrm{~F} \\
47 & \mathrm{~F} \\
37 & \mathrm{M} \\
49 & \mathrm{M}\end{array}$ & $\begin{array}{l}\text { Butobarbitone } \\
\text { Butobarbitone } \\
\text { Phenobarbitone } \\
\text { Phenobarbitone }\end{array}$ & $\begin{array}{l}\text { Pharyngeal } \\
\text { Endotracheal } \\
\text { Tracheostomy } \\
\text { Endotracheal }\end{array}$ & $\begin{array}{l}\text { Spontaneous } \\
\text { Assisted } \\
\text { Assisted } \\
\text { Assisted }\end{array}$ & $\begin{array}{r}24 \\
30 \\
144 \\
60\end{array}$ \\
\hline
\end{tabular}

* The barbiturates were identified in dichloromethane extracts of plasma, urine or gastric aspirate by thin layer chromatography (Cochin and Daly, 1963) and by gas chromatography.

All the patients made a complete recovery from the acute episode, but one (Case 7) died later after a massive pulmonary embolism.

\section{Forced Diuresis}

Intravenous solutions were infused in the following sequence at the rate of $500 \mathrm{ml}$./hour ; 8 millimoles of potassium chloride were added to each $500-\mathrm{ml}$. bottle: (1) $500 \mathrm{ml}$. of $1.25 \%$ $(\mathrm{w} / \mathrm{v})$ sodium bicarbonate solution or $0.87 \%(\mathrm{w} / \mathrm{v})$ sodium chloride solution, (2) $500 \mathrm{ml}$. of $5 \%(\mathrm{w} / \mathrm{v})$ glucose solution, (3) $500 \mathrm{ml}$. of $0.87 \%(\mathrm{w} / \mathrm{v})$ sodium chloride solution, and (4) $500 \mathrm{ml}$. of $5 \%(\mathrm{w} / \mathrm{v})$ glucose solution. The sodium bicarbonate solution was used only in the patients with phenobarbitone poisoning, to raise the urine $\mathrm{pH}$ above 7.5. This has been shown to increase the urinary excretion of phenobarbitone and to have no effect on the excretion of the other barbiturates which have higher $p \mathrm{~K}_{\mathrm{a}}$ values (Bloomer, 1966). Serum and urine electrolyte concentrations were checked every six hours.

A pair of patients had received each barbiturate. In one patient a three-hour period of mannitol-induced diuresis (10$20 \mathrm{~g}$./hour) was interpolated between two three-hour periods of frusemide-induced diuresis $(30 \mathrm{mg}$. intravenously at the beginning of each period). In the second patient a three-hour period of frusemide diuresis was interpolated between two periods of mannitol diuresis. In order to reduce interactions between diuretics there was an interval of one hour between successive diuretic periods during which no diuretic was given. Thus each patient received both diuretics, and changes in barbiturate excretion due to progressive alteration in renal vascular perfusion were not confused with changes due to diuretics.

Urine was collected through a urethral catheter into a closed system and a series of hourly samples was obtained. A mean urine flow of approximately $500 \mathrm{ml}$./hour was the target. The infusion rate was adjusted so that the cumulative water imbalance did not exceed 2 litres in either direction.

\section{Extraction Methods}

The concentration of unchanged barbiturate hypnotic in urine was determined by the gas-liquid chromatography of 
dichloromethane extracts. Parallel estimates on the same extracts were made by spectrophotometry. Plasma concentrations were determined by spectrophotometry after dichloromethane extraction. Estimates of total derivatives of barbituric acid (unchanged hypnotic and metabolites) were made by spectrophotometry after cyclohexanol extraction of urine.

Unchanged barbiturate was extracted by a modification of the method of Goldbaum (1952). Five-millilitre samples of urine were mixed with $3 \mathrm{ml}$. of $\mathrm{N} \mathrm{HCl}$ and extracted with three $10-\mathrm{ml}$. volumes of redistilled alkali-washed dichloromethane. These were combined and washed with $5 \mathrm{ml}$. of sodium phosphate buffer $(0.5 \mathrm{M}, \mathrm{pH} 7.4)$. Two-millilitre samples of oxalated plasma or serum were mixed with $5 \mathrm{ml}$. of sodium acetate buffer (0.1 M, pH 5) and extracted as for urine.

Total derivatives of barbituric acid (unchanged hypnotic and metabolites) were extracted by the method of Moss (1965). Two-millilitre samples of urine were mixed with $1 \mathrm{ml}$. of $\mathbf{N}$ $\mathrm{HCl}$ and extracted with $10 \mathrm{ml}$. of cyclohexanol. The extract was washed with $1 \mathrm{ml}$. of $5 \%(\mathrm{w} / \mathrm{v})$ sodium bicarbonate solution.

\section{Drug Identification}

The unchanged barbiturates were identified in dichloromethane extracts of plasma, urine, or gastric aspirate by thin layer chromatography (Cochin and Daly, 1963) and by gasliquid chromatography.

\section{Quantitative Measurement}

The concentration of unchanged barbiturate was determined by gas-liquid chromatography by means of a Pye 104, model 24 chromatograph with dual flame ionization detectors. The column support, Gaschrome $Z^{1}$ (100-120 mesh), was acidwashed and treated with dichlorodimethysilane as described by McMartin and Street (1966). The support was coated with Apiezon $\mathrm{L}^{2}$ (5 g. $/ 100$ g.) and operated with a nitrogen flow of $50 \mathrm{ml} . / \mathrm{min}$. Resolution of a mixture of eight barbiturates could be achieved with an initial isothermal period at $145^{\circ} \mathrm{C}$. followed by a linear gradient of $2^{\circ} \mathrm{C}$. min. and a final period at $200^{\circ}$ C. The method was similar to that described by Brochmann-Hanssen and Svendsen (1962).

Dichloromethane extracts were prepared for gas-liquid chromatography by vacuum distillation and the addition of known amounts of barbitone as internal standard. The columns were operated isothermally at temperatures between 180 and $200^{\circ} \mathrm{C}$. The measure of barbiturate concentration was the ratio of the area under the barbiturate peak to the area under the barbitone peak. These areas were determined by planimetry. The system was calibrated with the use of equimolar mixtures of the barbituric acid derivatives.

The spectrophotometric method of Goldbaum (1952) was used. Samples of barbiturate at $p H 10.5$ and $p H 13.5$ were scanned from a wavelength of 225 to $275 \mathrm{~m} \mu$ in the Unicam SP800 recording spectrophotometer. The difference in extinction at $260 \mathrm{~m} \mu$ was used as the measure of barbiturate concentration. Calibration curves were prepared from a pentobarbitone standard. Barbiturate concentrations were determined in molar terms and then expressed as milligrams of the appropriate barbiturate per $100 \mathrm{ml}$.

Known amounts (100-250 $\mu$ g.) of pentobarbitone and amylobarbitone were added to $5-\mathrm{ml}$. aliquots of urine from normal subjects. The mean recovery of barbiturate in dichloromethane extracts of 10 samples was $92 \% \pm 3 \%$ (S.E.).

Cyclohexanol extracted not only the more polar metabolites but also the unchanged barbiturate hypnotic. Thus if the resi-

\footnotetext{
1 Applied Science Laboratories Inc., State College, Pennsylvania.

${ }^{2}$ Edwards High Vacuum Ltd., Crawley, Sussex.
}

dual aqueous phase was extracted again with dichloromethane only traces of barbiturate were obtained.

Individual metabolites were not identified. The spectrophotometric method gave an estimate of the total molar concentration of all the compounds which contained the barbituric acid ring structure. The final concentration was expressed in milligrammes of the unchanged barbiturate.

\section{Plasma Barbiturate Clearance}

The results have been expressed in the form of the ratio $U / P$ and the plasma clearance of unchanged barbiturate hypnotic, $\mathrm{U} / \mathrm{P} \times \mathrm{V}$. $\mathrm{U}(\mathrm{mg} . / 100 \mathrm{ml}$.) represents the concentration of unchanged barbiturate hypnotic in the urine. $P(\mathrm{mg} . / 100 \mathrm{ml}$.) represents the concentration of unchanged barbiturate in the plasma determined by spectrophotometry once during each three-hour diuretic period. This value included the proportion which was protein bound.

\section{Urine pH and Electrolyte Content}

The urine $p H$ was measured at the end of each hour in the patients with phenobarbitone poisoning. The E.I.L. direct reading $\mathrm{pH}$ meter was standardized with buffers from British Drug Houses Ltd.

Sodium and potassium ion concentrations were determined by flame photometry on pooled aliquots of urine which were representative of three-hour collections. Three analyses were made in each patient.

\section{Analysis of Variance}

The analysis of variance outlined in Table IV was carried out according to a standard method (Goldstein, 1964).

\section{Results}

The rates of excretion of unchanged barbiturates and metabolic derivatives are shown in Table II. The urine excreted in nine hours contained up to $210 \mathrm{mg}$. of phenobarbitone and butobarbitone, up to $100 \mathrm{mg}$. of pentobarbitone, and less than $50 \mathrm{mg}$. of amylobarbitone.

The apparent rate of excretion of unchanged hypnotic was increased up to two and a half times when the barbiturate content of dichloromethane extracts was determined by spectrophotometry. The discrepancy between butobarbitone estimates

TABLE II.-Barbituric Acid Derivatives Excreted in Urine During Nine Hours of Forced Diuresis

\begin{tabular}{c|c|c|c|c|c|c}
\hline & & & & \multicolumn{3}{|c}{ Urine Barbiturate Excretion } \\
& & & & & \\
(mg./hr.)
\end{tabular}

* Plasma barbiturate concentration at the start of the forced diuresis. 
by gas-liquid chromatography and by spectrophotometry was small.

The unchanged pentobarbitone, amylobarbitone, and quinalbarbitone excreted in Cases $1-4$ represented $6-14 \%$ of the total barbiturate derivatives extracted from urine by cyclohexanol. Unchanged phenobarbitone represented $38-66 \%$ of the total derivatives extracted by cyclohexanol. Unchanged butobarbitone represented $62-81 \%$ of the total derivatives extracted by cyclohexanol.

The ratio of the concentration of unchanged barbiturate hypnotic in urine ( $\mathrm{U} \mathrm{mg./100} \mathrm{ml.)} \mathrm{to} \mathrm{the} \mathrm{concentration} \mathrm{in}$ plasma (P mg./100 ml.) was determined for each hourly urine sample. Table III shows the values for $100 \times U / P$ obtained in each of the eight patients. Three values are obtained during the second diuretic period. These were compared with the mean value of $100 \times U / P$ for the first hour of the first and third diuretic periods, and the corresponding mean values for the second and third hours of these periods. Thus 24 values were obtained during mannitol diuresis and 24 during frusemide diuresis. The mean value for mannitol was 63 and for frusemide 53 .

TABLE III.-Ratio $(100 \times U / P)$ of Concentration of Unchanged Barbiturate in Urine ( $U \mathrm{mg} .1100 \mathrm{ml}$.) to Concentration in Plasma (P mg./100 ml.) during Forced Diuresis with Mannitol and Frusemide

\begin{tabular}{|c|c|c|c|c|c|c|c|c|}
\hline \multirow{2}{*}{ Diuretic } & \multicolumn{2}{|c|}{$\begin{array}{c}\text { Pento- } \\
\text { barbitone }\end{array}$} & \multicolumn{2}{|c|}{$\begin{array}{c}\text { Amylo- } \\
\text { barbitone }\end{array}$} & \multicolumn{2}{|c|}{$\begin{array}{c}\text { Buto- } \\
\text { barbitone }\end{array}$} & \multicolumn{2}{|c|}{$\begin{array}{l}\text { Pheno- } \\
\text { barbitone }\end{array}$} \\
\hline & Case 1 & Case 2 & Case 3 & Case 4 & Case 5 & Case 6 & Case 7 & Case 8 \\
\hline $\begin{array}{l}\text { Mannitol: } \\
\text { 1st hou: .. } \\
\text { 2nd hour } \\
\text { 3rd hour } \\
\text { Frusemide: }\end{array}$ & $\begin{array}{l}71 \\
71 \\
50\end{array}$ & $\begin{array}{l}40 \\
42 \\
39\end{array}$ & $\begin{array}{l}42 \\
51 \\
51\end{array}$ & $\begin{array}{l}26 \\
30 \\
29\end{array}$ & $\begin{array}{l}102 \\
117 \\
112\end{array}$ & $\begin{array}{r}89 \\
109 \\
105\end{array}$ & $\begin{array}{l}60 \\
62 \\
67\end{array}$ & $\begin{array}{l}34 \\
46 \\
55\end{array}$ \\
\hline $\begin{array}{l}\text { 1st hour.. } \\
\text { 2nd hour } \\
\text { 3rd hour }\end{array}$ & $\begin{array}{l}64 \\
70 \\
71\end{array}$ & $\begin{array}{l}41 \\
42 \\
37\end{array}$ & $\begin{array}{l}37 \\
39 \\
49\end{array}$ & $\begin{array}{l}20 \\
23 \\
25\end{array}$ & $\begin{array}{l}76 \\
85 \\
94\end{array}$ & $\begin{array}{l}67 \\
66 \\
82\end{array}$ & $\begin{array}{l}38 \\
62 \\
64\end{array}$ & $\begin{array}{l}33 \\
35 \\
41\end{array}$ \\
\hline
\end{tabular}

Analysis of the variance of $100 \times U / P$ (Table IV) showed that variance due to differences between diuretics was smaller than variance due to differences between barbiturates or due to differences between subjects. The $P$ values of the corresponding variance ratios were of the same order.

TABLE IV.-A'nalysis of :he Variance of the Ratio $(100 \times U / P)$

\begin{tabular}{|c|c|c|c|c|c|}
\hline $\begin{array}{l}\text { Source of } \\
\text { Variation }\end{array}$ & $\begin{array}{l}\text { Sum of } \\
\text { Squares }\end{array}$ & $\begin{array}{c}\text { Degrees of } \\
\text { Freedom }\end{array}$ & Variance & $\begin{array}{l}\text { Variance } \\
\text { Ratio F }\end{array}$ & $\mathbf{P}$ \\
\hline 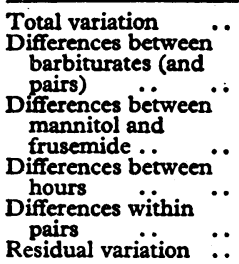 & $\begin{array}{r}30,210 \\
21,216 \\
1,187 \\
621 \\
4,202 \\
2,984\end{array}$ & $\begin{array}{r}1 \\
2 \\
1 \\
40\end{array}$ & $\begin{array}{r}1,187 \\
310 \\
4,202 \\
75\end{array}$ & $\begin{array}{r}16 \\
4 \\
56\end{array}$ & $\begin{array}{l}<0.01 \\
<0.01 \\
<0.05 \\
<0.01\end{array}$ \\
\hline
\end{tabular}

The mean urine flow rate $(\mathrm{V})$ produced in response to $60 \mathrm{~g}$. of mannitol over three hours was $6.9 \mathrm{ml} . / \mathrm{min}$. The mean urine flow rate during the three hours after the intravenous injection of $30 \mathrm{mg}$. of frusemide was $10.9 \mathrm{ml} . / \mathrm{min}$. The corresponding mean values for the plasma clearance $(\mathrm{U} \times \mathrm{V} /$ $\mathrm{P} \mathrm{ml./min.)} \mathrm{of} \mathrm{unchanged} \mathrm{barbiturate} \mathrm{hypnotic} \mathrm{are} \mathrm{shown} \mathrm{in}$ Table V. The plasma clearance during frusemide diuresis was greater despite the lower value for $U / P$, because the rate of urine flow was greater.

TABLE V.-Mean Plasma Clearance of Unchanged Barbiturate in Response to Diuresis Induced by Mannitol and Frusemide

\begin{tabular}{|c|c|c|c|c|c|}
\hline Diuretic & & $\begin{array}{l}\text { Dose in } \\
\text { 3 Hours }\end{array}$ & $\begin{array}{l}\text { Mean } \\
\text { Urine Flow } \\
\text { V ml./min. }\end{array}$ & $\underset{\text { U/P }}{\text { Mean Ratio }}$ & $\begin{array}{c}\text { Mean Plasma } \\
\text { Clearance } \\
\mathbf{U} \times \underset{\text { min }}{\mathbf{V} / \mathbf{P}} . / \\
\text { min. }\end{array}$ \\
\hline $\begin{array}{l}\text { Mannitol } \\
\text { Frusemide }\end{array}$ & $\ldots$ & $\begin{array}{l}60 \mathrm{~g} . \\
30 \mathrm{mg} .\end{array}$ & $\begin{array}{r}6.9 \\
10.9\end{array}$ & $\begin{array}{l}0.63 \\
0.53\end{array}$ & $\begin{array}{l}4 \cdot 3 \\
5.8\end{array}$ \\
\hline
\end{tabular}

The urine from the patients with phenobarbitone poisoning had a mean $\mathrm{pH}$ of 7.8 (7.7-7.9) during mannitol diuresis and 7.2 (6.5-7.9) during frusemide diuresis.

The urine produced during the mannitol diuresis had a sodium ion concentration of $65 \pm 25$ (S.D.) $\mathrm{mEq} / 1$. and a potassium ion concentration of $16 \pm 7$ (S.D.) $\mathrm{mEq} / \mathrm{l}$. The corresponding concentrations during the frusemide diuresis were $95 \pm 22$ and $14 \pm 6 \mathrm{mEq}$./ 1 . The intravenous infusion had a mean sodium ion concentration of $75 \mathrm{mEq} / 1$. and a potassium ion concentration of $16 \mathrm{mEq} / \mathrm{l}$. The lowest serum sodium ion concentration observed after a copious frusemide diuresis was $130 \mathrm{mEq} / 1$. There were no complications attributable to sodium ion imbalance.

\section{Discussion}

The quantitatively important mode of elimination of pentobarbitone or amylobarbitone in Cases 1-3 and of amylobarbitone and quinalbarbitone in Case 4 was biotransformation of the hypnotic and excretion of its metabolites.

During nine hours of forced diuresis in the severely poisoned patient (Case 4) the unchanged barbiturate in the urine represented less than the content of one 100-mg. capsule (Tuinal). These results agree with those obtained in pentobarbitone and quinalbarbitone poisoning by Bloomer (1965, 1966). The greater excretion rates of unchanged pentobarbitone and amylobarbitone observed in seriously poisoned patients by Linton et al. (1967) were probably due to simultaneous extraction and estimation of more polar metabolites (Bloomer, 1967). The clinical response to full supportive treatment without forced diuresis in patients with severe poisoning due to these barbiturates is very satisfactory (Matthew, 1967, personal communication). Thus it is difficult to believe that the very small amounts of pentobarbitone, amylobarbitone, and quinalbarbitone removed by forced diuresis have any therapeutic significance.

If forced diuresis increased the rate of excretion of the metabolites of these barbiturates, a case might still be made for its use ; rapid removal of metabolites might increase the rate of barbiturate hydroxylation. Also the metabolites themselves may have toxic effects in man. Hydroxyamylobarbitone, for example, has half the hypnotic potency of amylobarbitone in the mouse (Irrgang, 1965). However, the plasma clearance of pentobarbitone metabolites approximated to the glomerular filtration rate as determined by creatinine clearance (Bloomer, 1965), so no increase by forced diuresis could be expected.

Excretion of the unchanged barbiturate was of relatively greater importance in the patients with phenobarbitone poisoning. The results suggest that the apparent phenobarbitone excreted by the patients of Linton et al. (1967) may have been about half phenobarbitone and half metabolite.

The estimates of butobarbitone excretion by gas-liquid chromatography and by spectrophotometry differed little. This confirms the excretion rates reported by Linton et al. (1967). The elimination of butobarbitone metabolites appeared to be quantitatively less important.

The ratio $U / P$ was greater with mannitol than with frusemide. However, this difference was of no greater significance than differences between barbiturates or differences between subjects (Table IV). These results support the decision of Linton et al. (1967) to abandon the use of mannitol in favour of the more convenient frusemide.

There is evidence that the intravenous infusion of hypertonic solutions of mannitol can be harmful. One of us (H.A.L.) observed pulmonary oedema despite external water balance in two cases of barbiturate poisoning treated by mannitol diuresis (unpublished observations, 1967). G. Morgan and A. Polak (personal communication, 1968) had a similar experience. They measured the distribution and excretion of mannitol after intravenous infusion in 23 cases of salicylate or barbiturate poison- 
ing. Mannitol was retained during the forced diuresis, and there appeared to be a net movement of water from the intracellular to the extracellular space.

$\mathrm{Had}$ the urine $\mathrm{pH}$ values during the frusemide diuresis and the mannitol diuresis been better matched the differences in $\mathrm{U} / \mathrm{P}$ for phenobarbitone (Table III) would have been reduced further. Bloomer (1966) showed that when the urine $p H$ was increased from 7.5 to 8 the ratio $U / P$ for phenobarbitone was increased twofold to threefold. Similar considerations do not affect pentobarbitone, amylobarbitone, quinalbarbitone, and butobarbitone, for these drugs have $p \mathrm{~K}_{a}$ values of the same order as the upper limit of urine $\mathrm{pH}$ in man (Krahl, 1940). $\mathbf{U} / \mathbf{P}$ for pentobarbitone and quinalbarbitone was not significantly increased by making the urine alkaline (Bloomer, 1966).

\section{Conclusions}

No worth-while benefit stems from the use of forced diuresis in the treatment of severe intoxication with pentobarbitone, amylobarbitone, and quinalbarbitone.

It is reasonable to use forced diuresis in severe poisoning by butobarbitone or phenobarbitone, since the unchanged hypnotic is a prominent component of the barbiturate derivatives excreted in the urine. For this purpose frusemide is not inferior to mannitol.

\section{Summary}

Eight patients with acute barbiturate poisoning have each been treated by periods of forced diuresis with mannitol and with frusemide.

The urinary excretion of unchanged barbiturate hypnotic has been determined by gas-liquid chromatography and the excretion of total barbituric acid derivatives by spectrophotometry.

The unchanged hypnotic represented only $6-14 \%$ of the total urinary barbituric acid derivatives excreted by patients poisoned with pentobarbitone, amylobarbitone, or amylobarbitone plus quinalbarbitone. The excretion of unchanged hypnotic did not exceed $100 \mathrm{mg}$. in nine hours and probably had no therapeutic significance.

The proportion of the total urinary barbituric acid derivatives excreted as unchanged phenobarbitone or butobarbitone varied from 38 to $81 \%$.

Mannitol appeared to have no important practical advantages over frusemide as a means of inducing diuresis.

It is concluded that forced diuresis with frusemide may reasonably be used in the treatment of severe poisoning with butobarbitone or phenobarbitone but that there is no indication for forced diuresis in poisoning due to pentobarbitone, amylobarbitone, or quinalbarbitone.

The patients were admitted to the care of Professor D. A. K. Black in the Manchester Royal Infirmary. Sister Officer and her staff in the respiratory care unit were responsible for the determinations of urinary flow rate and for the detailed labelling of urine samples. Mrs. M. Rodgers gave able technical assistance. The following firms gave chromatographic standards of drugs: Bayer Products Co., British Drug Houses Ltd., Eli Lilly \& Co. Ltd., Geigy (U.K.) Ltd., May and Baker Ltd., and A. Wander Ltd.

The investigation was supported by the Research Grants Committee of the United Manchester Hospitals.

\section{REFERENCES}

Bloomer, H. A. (1965). New Engl. F. Med., 272, 1309.

Bloomer, H. A. (1966) f. Lab. clin. Med., 67, 898. Bloomer, H. A. (1967). Lancet, 2, 986.

Brochmann-Hanssen, E., and Svendsen, A. B. (1962). F. pharm. Sci., $51,318$.

Cochin, J., and Daly, J. W. (1963). F. Pharmacol. exp. Ther., 139, 154. Goldbaum, L. R. (1952). Analyt. Chem., 24, 1604.

Goldstein, A. (1964). Biostatistics. London.

Goldstein, A. (1964). Biostatistics. London. 688.

Irrgang, K. (1965): Arzneimittel-Forsch, 15, 688.

Linton, A. L., Luke, R. G., and Briggs, J. D. (1967). Lancet, 2, 377.

McMartin, C., and Street, H. V. (1966). F. Chromat., 22, 274.

Moss, M. S. (1965). Proc. Ass. clin. Biochem., 3, 218.

Varley, H. (1967). Practical Clinical Biochemistry, 4th ed. London.

\title{
Horseshoe Kidney, Renal Arterial Anomalies, and Hypertension : a Study of One Family
}

\author{
P. W. ROBERTSON,* M.D., F.R.C.P.
}

Brit. med. F., 1968, 2, 793-797

Horseshoe kidney is a well-recognized congenital malformation. The frequency with which it may occur has been variously estimated at between 1 in 400 of the general population (Glenn, 1959) and 1 in 1,000 (Walters and Priestley, 1932). Bell (1950) noted its occurrence in 119 necropsies out of a series of 59,064, giving an incidence of 1 in 497. Males are said to be rather more often affected than females.

Horseshoe kidney occurs from the fusion of the renal blastomas at a very early stage of foetal development, variously given as fourth to eighth week (Glenn) and eighth to tenth week (Bell). At this stage the lower poles of the primitive renal structures are in close proximity (it is very rare for the anomaly to cause fusion of the upper poles, producing an inverted horseshoe, but this can occur; so can total fusion, giving a cake or plate kidney). This early maldevelopment carries with it a persistence of the more primitive arterial supply arising from iliac arteries, lower aorta, or, very rarely, inferior mesenteric artery.

\footnotetext{
- Consultant Physician, East Birmingham Hospital, Birmingham 9.
}

Association of multiple renal arteries with horseshoe kidney does not seem to be particularly well known, though a careful examination of the text and the illustrations of many past papers does indicate the presence of multiple renal arteries. Thus Glenn's paper referred to eight patients who had been explored surgically, and specifically noted the presence of accessory renal arteries in seven of these.

In a recent study (Robertson et al., 1967) attention was drawn to the invariable finding of multiple and anomalous renal arteries in horseshoe kidney investigated by angiography. It was also noted that, in some instances at least, various members of the same family had multiple renal arteries, and it was suggested that in some families with a strong family history of "essential hypertension" the inherited factor might be renal dysplasia.

We have often noticed the similarity in renal shape between many of the kidneys with multiple renal arteries in our hypertensive patients-the rather sausage-shaped structures-and the shape of the vertical limbs of the horseshoe. Variations in horseshoe shape and in the shape of multiple-artery kidneys have suggested that all these might be similar malformations varying 